\title{
Uznanie okoliczności faktycznych za udowodnione w świetle czynnego udziału podatnika w procedurze podatkowej
}

\author{
Recognizing facts as proven in the light \\ of a taxpayer's active participation in a tax \\ procedure
}

Streszczenie. Przedmiotem artykułu są zagadnienia związane z uznaniem okoliczności faktycznych za udowodnione w świetle czynnego udziału strony w postępowaniu podatkowym na gruncie art. 192 Ordynacji podatkowej. Autor podkreśla, że w myśl przepisu art. 192 o.p. zapewnienie podatnikowi możliwości wypowiedzenia się co do wszelkich przeprowadzonych dowodów warunkuje dopiero uznanie danej okoliczności za udowodnioną. Oznacza to, że przyjęcie przez czynny podmiot stosunku podatkowoprawnego nowych ustaleń jako udowodnionych z naruszeniem art. 192 o.p. stanowi wystarczającą przesłankę do uznania rozstrzygnięcia podatkowego za wadliwe. Artykuł zamyka się konkluzją, zgodnie z którą organ podatkowy nie może oprzeć się na dowodzie, z którym 
podatnik nie miał możliwości zapoznania się oraz wypowiedzenia na jego temat. Zatem nawet najlepiej zebrany w sprawie podatkowej materiał dowodowy nie może mieć jakiejkolwiek wartości, jeżeli nie został spełniony wymóg określony w przepisie art. 192 o.p.

Słowa kluczowe: podatnik; procedura podatkowa; zasada czynnego udziału strony; okoliczność faktyczna; dowód.

\begin{abstract}
This article is dedicated to the recognition of facts as proven in the light of a party's right to an active participation in a tax proceeding conducted on the basis of Article 192 of the Tax Ordinance Act (TO). The author emphasised that pursuant to Article 192 of the TO the taxpayer's opportunity to speak as regards all evidence taken in his/her case is determined only by the recognition of a given circumstance as proven. This means, that an active party's recognition of new findings would be a sufficient premise to conclude that a tax decision is defective if it infringed Article 192 TO. The author concluded that a tax authority cannot base its decisions on the evidence if the taxpayer had no opportunity to examine or to speak about this evidence his/her case. Therefore, even if the evidence in the tax procedure was collected with a great care, it cannot be of any value if the requirement specified in the Article 192 TO has not been met.
\end{abstract}

Keywords: taxpayer; tax procedure; principle of an active participation of a party; facts; evidence.

\title{
1. Uwagi wprowadzające
}

Zasadniczym celem artykułu jest dokonanie ustaleń dotyczących gwarancyjnej funkcji zasady ogólnej czynnego udziału strony w postępowaniu podatkowym w świetle uznania okoliczności faktycznych za udowodnione na gruncie art. 192 Ordynacji podatkowej ${ }^{1}$. To właśnie w art. 192 o.p. prawodawca stanowi, że okoliczność faktyczna może być uznana za udowodnioną, jeżeli podatnik miał możliwość wypowiedzenia się co do przeprowadzonych dowodów.

1 Ustawa z dnia 29 sierpnia 1997 r. Ordynacja podatkowa (tekst jedn. Dz.U. z 2018 r. poz., 800 ze zm.), dalej: o.p. 
Opracowanie ma przede wszystkim na celu podjęcie wieloaspektowej, choć oczywiście niepełnej, analizy instytucji z art. 192 o.p. na gruncie procedury podatkowej przy wykorzystaniu wypracowanego przez judykaturę i doktrynę dorobku w tym zakresie. Przedstawione wywody koncentrują się wokół kwestii budzących najwięcej wątpliwości lub wymagających rozważenia w nowym świetle, m.in. włączania dowodów z innych postępowań do procesu podatkowego czy następstw prawnych naruszeń prawa podatnika do wypowiedzenia się co do przeprowadzonych dowodów. Na tej płaszczyźnie autor zwraca uwagę, że uchybienie obowiązku wynikającego z art. 192 o.p. w związku z art. 123 o.p. i 200 o.p. w postaci nieumożliwienia stronie wypowiedzenia się co do zebranego materiału dowodowego skutkuje nieuznaniem okoliczności faktycznych, wynikających ze zgromadzonego materiału, jako faktów udowodnionych.

\section{Brak równorzędności stron stosunku podatkowoprawnego}

Postępowanie podatkowe nie ma charakteru kontradyktoryjnego ${ }^{2}$, ponieważ stosunek prawny łączący organ podatkowy i stronę jest stosunkiem administracyjnoprawnym, charakteryzującym się nadrzędną pozycją organu procesowego, dysponującego władztwem podatkowym ${ }^{3}$. Oznacza to, że prawo podatkowe przyznaje czynnemu podmiotowi stosunku podatkowoprawnego uprawnienie do orzekania w sposób wiążący względem dłużnika podatkowego poprzez możliwość jednostronnego i władczego decydowania o jego sferze prawnej ${ }^{4}$. Innymi słowy, rozstrzyganie sporów powstających na gruncie stosunku podatkowoprawnego następuje w try-

2 B. Brzeziński, M. Masternak, O tak zwanym ciężarze dowodu w postępowaniu podatkowym, „Przegląd Podatkowy” 2004, nr 5, s. 57; I. Nowak, Ciężar dowodzenia w postępowaniu podatkowym - podstawowe problemy [w:] B. Kucia-Guściora (red.), M. Münnich (red.), A. Zdunek (red.), R. Zieliński (red.), Stanowienie i stosowanie prawa podatkowego w Polsce. Ocena i kierunki zmian, Lublin 2016, s. 183 i n.; wyrok WSA w Poznaniu z dnia 23 lipca 2015 r., I SA/Po 122/15, Centralna Baza Orzeczeń Sądów Administracyjnych (CBOSA).

3 Wyrok NSA z dnia 11 kwietnia 2012 r., II FSK 1921/10, CBOSA.

4 Wyrok WSA w Gdańsku z dnia 26 czerwca 2013 r., I SA/Gd 605/13, CBOSA. 
bie szczególnego postępowania administracyjnego ${ }^{5}$, które nie jest prowadzone przez niezależnego arbitra, lecz przez organ podatkowy wyposażony w odpowiednie „narzędzia prawne” do władczego wkraczania w sferę uprawnień i obowiązków podatnika ${ }^{6}$. W związku z tym powstaje „relacja prawna” oparta na nierównorzędności podmiotów (stosunek nadrzędności) i pojawia się władztwo (imperium) dysponenta, czyli organu administracji publicznej ${ }^{7}$. Zwraca na to uwagę również orzecznictwo sądowe, zauważając, że procedura podatkowa nie jest postępowaniem kontradyktoryjnym, a stosunek podatkowoprawny zachodzący pomiędzy podmiotami nie ma charakteru równorzędnego, tak jak ma to miejsce relacjach cywilnoprawnych ${ }^{8}$.

W stosunku materialno-prawnym opartym na władztwie administracyjnoprawnym status podatnika jest oczywiście słabszy, a jego możliwości „ingerowania” w tę relację ograniczone. Podkreślić w związku z tym należy, że ustawodawca w celu wzmocnienia pozycji podatnika w procesie inkwizycyjnym ustanowił zasady ogólne - w tym zasadę czynnego udziału strony - aby zagwarantować jej ochronę wobec władczych działań

5 R. Mastalski, Stosowanie prawa podatkowego 2008, Lex/el; tenże Tworzenie prawa podatkowego a jego stosowanie 2016, Lex/el.

6 Wyrok WSA w Gdańsku z dnia 21 grudnia 2010 r., I SA/Gd 1115/10, CBOSA; wyrok WSA w Gorzowie Wielkopolskim z dnia 20 października 2011 r., II SA/Go 611/11, CBOSA; wyrok WSA w Gorzowie Wielkopolskim z dnia 27 października 2011 r., II SA/Go 619/11, CBOSA; wyrok WSA w Gdańsku z dnia 30 stycznia 2013 r., I SA/Gd 946/12, CBOSA; wyrok WSA w Gdańsku z dnia 26 czerwca 2013 r., I SA/Gd 605/13, CBOSA.

7 A. Mariański, Rozstrzyganie wątpliwości na korzyść podatnika. Zasada prawa podatkowego, Warszawa 2009, s. 18 i n.; wyrok WSA w Gliwicach z dnia 16 stycznia 2009 r., III SA/Gl 305/08, CBOSA; wyrok WSA w Poznaniu z dnia 23 lipca 2015 r., I SA/Po 124/15, CBOSA.

8 „Prawo cywilne i prawo podatkowe to bowiem dwie autonomiczne gałęzie prawa, sytuujące się po dwóch różnych stronach dychotomicznego podziału prawa na prawo prywatne i prawo publiczne, tak więc poszczególne ich instytucje, chociaż wzajemnie na siebie oddziaływują, to jednak zachowują względem siebie daleko idąca niezależność" - wyrok WSA w Rzeszowie z dnia 19 kwietnia 2016 r., I SA/Rz 213/16, CBOSA; podobnie B. Brzeziński, Prawo podatkowe a prawo cywilne [w:] B. Brzeziński (red.), Prawo podatkowe. Teoria. Instytucje. Funkcjonowanie, Toruń 2009, s. 391 i n. 
organów administracyjnych ${ }^{9}$ tak, aby stała się podmiotem, a nie przedmiotem toczącej się procedury podatkowej ${ }^{10}$.

\section{Uznanie okoliczności faktycznych za udowodnione a zasady ogólne procedury podatkowej}

Według art. 192 o.p. okoliczność faktyczna może być uznana za udowodnioną, jeżeli strona miała możliwość wypowiedzenia się co do przeprowadzonych dowodów. $\mathrm{Z}$ przepisu tego wynika, że zebrane w postępowaniu podatkowym dowody tylko wtedy będą mogły stanowić podstawę ustalenia stanu faktycznego, jeżeli podatnik miał możliwość wypowiedzenia się co do nich ${ }^{11}$. A contrario, okoliczności faktyczne ustalone w procesie podatkowym, w którym strona nie miała możliwości wzięcia udziału i wypowiedzenia się co do przeprowadzonych dowodów przed wydaniem rozstrzygnięcia podatkowego, nie mogą być uznane za udowodnione (art. 192 o.p.) ${ }^{12}$. Analogiczne stanowisko można odnaleźć w orzecznictwie sądów administracyjnych, w którym sformułowany został trafny pogląd, że z treści art. 192 o.p. jednoznacznie wynika, iż pomiędzy postępowaniem dowodowym a umożliwieniem dłużnikowi podatkowemu wypowiedzenie się co do zebranych dowodów istnieje ścisły związek, oznaczający, że nawet najbardziej gruntownie zebrane w tej procedurze dowody tylko wtedy będą mogły stanowić podstawę do ustalenia stanu faktycznego, jeżeli podatnik miał możliwość wypowiedzenia się. W przeciwnym wypadku zaniedbanie tego obowiązku sprawia, że dowody, co do których podatnik nie

9 Wyrok WSA w Warszawie z dnia 13 grudnia 2004 r., III SA/Wa 189/04, CBOSA.

10 Por. M. Wierzbowski, A. Wiktorowska, Zagadnienia ogólne [w:] M. Wierzbowski (red.), Postępowanie administracyjne - ogólne, podatkowe, egzekucyjne i przed sq̨dami administracyjnymi, Warszawa 2017, s. 24.

11 Wyrok WSA w Kielcach z dnia 29 maja 2008 r., I SA/Ke 90/08, CBOSA; wyrok WSA we Wrocławiu z dnia 10 stycznia 2013 r., I SA/Wr 1158/12, CBOSA.

12 Por. wyrok NSA z dnia 25 kwietnia 1996 r., SA/Wr 2294/95, Lex/el; H. KnysiakMolczyk (red.), Kodeks postępowania administracyjnego. Komentarz 2015, (komentarz do art. 81), Lex/el. 
miał możliwości wypowiedzenia, są „bezwartościowe” i nie będą mogły być wykorzystane do udowodnienia jakiejkolwiek okoliczności ${ }^{13}$.

Instytucję uznania okoliczności faktycznej za udowodnioną w ramach art. 192 o.p. konkretyzują bezpośrednio dwie zasady ogólne tejże procedury: czynnego udziału strony/wysłuchania strony (art. 123 o.p.) $)^{14}$ oraz prawdy materialnej/obiektywnej (art. 122 o.p.) ${ }^{15}$. Natomiast pośrednio zasada praworządności/legalizmu (art. 120 o.p.), zasada prowadzenia postępowania podatkowego w sposób budzący zaufanie do organów podatkowych (art. 121 o.p.) oraz zasada przekonywania (art. 124 o.p.) ${ }^{16}$. Także w doktrynie prawa podatkowego oraz orzecznictwie sądowym panuje zgodny pogląd, że gwarancyjny wymiar art. 192 o.p. stanowi bezpośredni przejaw realizacji zasady czynnego udziału strony w postępowaniu oraz prawdy obiektywnej, zapewniając podatnikowi możliwość „współdziałania” z organami administracji podatkowej w procesie ustalania podstawy faktycznej rozstrzygnięcia podatkowego ${ }^{17}$.

Stosownie do art. 190 o.p. w kontekście art. 192 o.p. organ prowadzący szczególne postępowanie administracyjne obowiązany jest zapewnić podatnikowi czynny udział w każdym stadium procedury, w tym musi zawiadomić o miejscu i terminie przeprowadzenia dowodu z zeznań świadków, opinii biegłych lub oględzin wraz z możliwością brania udziału w przeprowadzaniu tych dowodów i zadawaniu pytań świadkom, bie-

13 L. Etel (red.), Nowa Ordynacja podatkowa. Z prac Komisji Kodyfikacyjnej Ogólnego Prawa Podatkowego, Białystok 2017, s. 465; wyrok NSA z dnia 27 marca 2003 r., SA/Rz 687/01, Legalis nr 62748; wyrok NSA z dnia 10 marca 2011 r., II FSK 1891/09, CBOSA; wyrok NSA z dnia 21 listopada 2013 r., II FSK 53/12, CBOSA.

14 P. Pietrasz, Komentarz do art. 192 o.p. [w:] L. Etel (red.), Ordynacja podatkowa. Komentarz aktualizowany 2018, Lex/el.

15 Wyrok NSA z dnia 23 sierpnia 2016 r., II FSK 2078/14, CBOSA.

16 Por. A. Wróbel, Komentarz do art. 81 k.p.a. [w:] A. Wróbel, M. Jaśkowska, M. Wilbrandt-Gotowicz, Komentarz aktualizowany Kodeksu postępowania administracyjnego 2018, Lex/el.

17 Por. R. Kędziora, Kodeks postępowania administracyjnego. Komentarz 2017, (komentarz do art. 81), Legalis/el; A. Hanusz, Podstawa faktyczna rozstrzygnięcia podatkowego 2004, Lex/el. 
głym oraz składaniu wyjaśnień ${ }^{18}$. Także w piśmiennictwie istnieje w zasadzie zgodność poglądów co do tego, że w praktyce realizacja uprawnienia określonego w art. 192 o.p. następuje w związku z wyznaczeniem przez organ podatkowy 7-dniowego terminu do wypowiedzenia się w sprawie zebranego materiału dowodowego, zgodnie z art. $200 \S 1$ o.p., będącego rozwinięciem następstw procesowych obowiązywania zasady ogólnej „wysłuchania strony” z art. 123 o.p. ${ }^{19}$. Trafne jest zatem stanowisko B. Dautera, że „artykuł 192 najczęściej jest stosowany w powiązaniu z art. $190 \S 1$ i 2 oraz art. $200 \S 1$. W tych dwóch przypadkach bowiem strona zawsze będzie mogła się wypowiedzieć co do przeprowadzonych dowodów. W pierwszym przypadku - uczestnicząc bezpośrednio w ich przeprowadzaniu, w drugim - analizując dowody zgromadzone już w aktach sprawy"20.

Dyspozycja przepisu art. $200 \S 1$ o.p., zawierająca konkretyzację normy ujętej w art. 123 o.p., stanowi procesową gwarancję realizacji uprawnień strony postępowania podatkowego w zakresie jej pełnego udziału w tej procedurze. Podatnik musi bowiem mieć prawną możliwość ustosunkowania się do poczynionych przez organy podatkowe ustaleń w każdej fazie procedury. Ma to z kolei na celu zapewnienie realizacji zasady zupełności procesu podatkowego, o której mowa w art. 122 o.p. i art. $187 \S 1$ o.p. ${ }^{21}$. Płynie z tego wniosek - o czym była mowa powyżej że przy ocenie, czy dana okoliczność jest udowodniona konkretnym dowodem, należy brać pod uwagę fakt, czy bierny podmiot stosunku podatkowoprawnego miał możliwość wypowiedzenia się odnośnie danego dowodu (art. 192 o.p.), ponieważ organ podatkowy powinien swoją ocenę dokonać w oparciu o całość zebranego i ujawnionego w stosunku do stro-

18 I. Nowak, Oględziny jako bezpośredni środek dowodowy w postępowaniu podatkowym, „Przegląd Podatków Lokalnych i Finansów Samorządowych” 2018, nr 11, s. 18 i n.; por. wyrok NSA z dnia 13 lutego 1986 r., II SA 2015/85, CBOSA.

19 Wyroki WSA w Lublinie z dnia 26 października 2011 r., I SA/Lu 519-520/11, CBOSA; wyrok WSA w Gliwicach z dnia 10 listopada 2016 r., I SA/Gl 1020/16, CBOSA.

20 B. Dauter, Komentarz do art. 192 o.p. [w:] S. Babiarz, B. Dauter, R. Hauser, A. Kabat, M. Niezgódka-Medek, J. Rudowski, Ordynacja podatkowa. Komentarz 2017, Lex/el.

21 Wyrok WSA w Kielcach z dnia 13 kwietnia 2006 r., I SA/Ke 513/05, CBOSA. 
ny materiału dowodowego ${ }^{22}$. Niezagwarantowanie więc podatnikowi lub działającemu w jego imieniu pełnomocnikowi możliwości wypowiedzenia się w sprawie zebranego materiału dowodowego ma istotne znaczenie dla rozstrzygnięcia podatkowego ${ }^{23}$, ponieważ ustawodawca w przepisie art. 192 o.p. zawarł „formułę prawna”, zgodnie z którą dana okoliczność faktyczna może być uznana z udowodnioną, jeżeli strona miała możliwość wypowiedzenia się co do zebranych dowodów ${ }^{24}$.

\section{Uznanie okoliczności faktycznych za udowodnione a prawo podatnika do wypowiedzenia się co do przeprowadzonych dowodów}

W świetle art. 192 o.p. podatnik jest uprawniony do zapoznania się z całym materiałem dowodowym i zajęcia stanowiska względem niego, a nie tylko części wybranej przez organ podatkowy ${ }^{25}$. Wystarczającą więc przesłanką, którą powinien zrealizować czynny podmiot stosunku podatkowoprawnego, ażeby okoliczność faktyczna mogła być uznana za udowodnioną, jest samo umożliwienie stronie wypowiedzenia się co do przeprowadzonych dowodów ${ }^{26}$. W istocie obowiązek ciążący na organie orzekającym może być zrealizowany w ten sposób, że podatnik weźmie udział w przeprowadzeniu określonego środka dowodowego (np. z zeznań

22 Wyrok NSA z dnia 24 listopada 2006 r., II FSK 1447/05, CBOSA; wyrok WSA w Krakowie z dnia 24 czerwca 2009 r., I SA/Kr 326/09, CBOSA.

23 I. Nowak, Pełnomocnik jako reprezentant strony w jurysdykcyjnym postępowaniu podatkowym - wybrane aspekty, „Przegląd Prawa Publicznego” 2013, nr 12, s. 45 i n.; I. Nowak, B. Rutkowski, Pełnomocnictwo w świetle Ordynacji podatkowej - stan obecny a planowane zmiany, „Toruński Rocznik Podatkowy” 2014/el, s. 184 i n.

24 I. Nowak, Skutki pominięcia pełnomocnika w sprawie podatkowej [w:] R. Frey (red.), Przemiany prawa publicznego i prywatnego na poczqtku XXI wieku, Kielce 2012, s. 199 i n.; wyrok NSA z dnia 19 czerwca 2001 r., III SA 750/00, Legalis nr 51424.

25 Wyrok WSA w Łodzi z dnia 30 stycznia 2012 r., I SA/Łd 1299/11, CBOSA; wyrok WSA we Wrocławiu z dnia 25 marca 2014 r., I SA/Wr 101/14, CBOSA; wyrok WSA w Warszawie z dnia 16 marca 2016 r., III SA/Wa 1080/15, CBOSA. Wyrok WSA w Gliwicach z dnia 17 lutego 2016 r., I SA/Gl 1385/15, CBOSA. 
świadków, wyjaśnień biegłych ${ }^{27}$, oględzin) lub zostanie zapoznany z wynikiem przeprowadzonego dowodu co do danej okoliczności faktycznej (np. dowodu z urzędu) ${ }^{28}$.

Uprawnienie z art. 192 o.p. organy władzy publicznej muszą respektować zawsze, gdy przeprowadzą określony dowód, niezależnie, czy będzie to miało miejsce w postępowaniu pierwszoinstancyjnym, czy też drugoinstancyjnym ${ }^{29}$. Co więcej, przepis art. 192 o.p. będzie miał „zastosowanie” w postępowaniu zwyczajnym (przed organem pierwszej instancji i w postępowaniu odwoławczym) oraz w postępowaniach nadzwyczajnych, jeżeli w tych trybach procesowych prowadzane będą czynności dowodowe $^{30}$. Także $\mathrm{w}$ przypadku przeprowadzenia przez organ odwoławczy w sprawie postępowania uzupełniającego będzie on zobowiązany przed wydaniem rozstrzygnięcia podatkowego umożliwić podatnikowi wypowiedzenie się co do zebranych dodatkowo dowodów ${ }^{31}$. Jednakże za niedopuszczalne należy uznać na etapie postępowania drugoinstancyjnego uzupełnienie przez organ podatkowy wyższego stopnia wady postępowania, polegającej na niewypełnieniu normy prawnej z art. 192 o.p., popełnionej przez organ pierwszoinstancyjny ${ }^{32}$. Innymi słowy, takiej wadliwo-

27 I. Nowak, Status biegłego i jego opinii jako dowodu w jurysdykcyjnym postępowaniu podatkowym, „Przegląd Podatków Lokalnych i Finansów Samorządowych” 2018, numery 4-6, s. 19-26/19-27/23-29.

28 Por. J. Borkowski, Komentarz do art. 81 k.p.a. [w:] J. Borkowski, J. Jendrośka, R. Orzechowski, A. Zieliński, Kodeks postępowania administracyjnego. Komentarz, Warszawa 1985, s. 161.

29 B. Brzeziński (red.), M. Kalinowski (red.), A. Olesińska (red.), Ordynacja podatkowa. Komentarz praktyczny, Gdańsk 2017, s. 945; B. Dauter, Komentarz do art. 192 o.p..., Lex/el; M. Münnich, Przebieg postępowania podatkowego (tryby zwyczajne i tryby nadzwyczajne) [w:] P. Smoleń (red.), W. Wójtowicz (red.), Prawo podatkowe, Warszawa 2017, s. 228.

30 Por. A. Wróbel, Komentarz do art. 81 k.p.a..., Lex/el; M. Terlikowska, Kodeks postępowania administracyjnego. Dowody. Komentarz 2017, (komentarz do art. 81), Legalis/el.

31 Por. P. Przybysz, Kodeks postępowania administracyjnego. Komentarz aktualizowany 2019, (komentarz do art. 81), Lex/el; wyrok NSA z dnia 3 października 1988 r., II SA 165/88, Lex/el; wyrok NSA z dnia 10 listopada 1995 r., SA/Gd 2571/94, Lex/el; wyrok NSA z dnia 17 lipca 2015 r., I OSK 164/14, CBOSA.

32 M. Terlikowska, Kodeks..., Legalis/el, A. Wróbel, Komentarz do art. 81 k.p.a..., Lex/el; por. wyrok WSA w Poznaniu z dnia 19 września 2018 r., II SA/Po 453/18, CBOSA; odmiennie E. Iserzon, Komentarz do art. 75 k.p.a. [w:] E. Iserzon, J. Staro- 
ści proceduralnej organ odwoławczy nie może konwalidować ${ }^{33}$, gdyż doszłoby nie tylko do naruszenia zasady dwuinstancyjności ${ }^{34}$, wyrażającej prawo podatnika do obrony swoich praw na gruncie postępowania podatkowego $^{35}$, ale także do naruszenia zasady zaufania do organu podatkowego, wyrażonej w art. $121 \S 1$ o.p., oraz czynnego udziału stron w procesie podatkowym, unormowanej w art. $123 \S 1$ o.p. ${ }^{36}$.

Podatnik jest uprawniony, nigdy zaś zobowiązany, do wypowiadania się na temat zgromadzonych dowodów ${ }^{37}$. To od strony zależy, czy skorzysta ona z przysługującego jej uprawnienia, czy też nie ${ }^{38}$. Zatem jeżeli dłużnik podatkowy nie wypowiedział się co do zebranego materiału dowodowego, chociaż organ podatkowy stworzył ku temu warunki, stan faktyczny będący podstawą rozstrzygnięcia może być przyjęty w oparciu o przeprowadzone dowody, bez naruszenia przepisu art. 192 o.p. ${ }^{39}$. Tak więc, gdy stronie umożliwiono zapoznanie się $\mathrm{z}$ aktami sprawy ${ }^{40}$, a ona z tego prawa nie skorzystała lub skorzystała, ale złożyła kolejne wnioski dowodowe, które dotyczyły okoliczności wykazanych innymi dowodami

ściak, Kodeks postępowania administracyjnego. Komentarz. Teksty. Wzory i formularze, Warszawa 1970, s. 168.

Z. Kmieciak, Odwołania w postępowaniu administracyjnym 2011, Lex/el; S. Presnarowicz, Zaskarżanie decyzji podatkowych w Polsce, Białystok 2014, s. 104 i n.; wyrok WSA w Gliwicach z dnia 12 września 2018 r., III SA/Gl 394/18, CBOSA.

34 Zob. I. Nowak, Zasada dwuinstancyjności a ochrona praw podatnika, „Kwartalnik Prawa Podatkowego" 2009, nr 2, s. 9 i n.

35 A. Mariański (red.), Podatnik w postępowaniu podatkowym, Warszawa 2006, s. 426 i n.; D. Strzelec, Naruszenia przepisów postępowania przez organy podatkowe, Warszawa 2009, s. 223 i n.; tenże Dowody i postępowanie dowodowe w prawie podatkowym 2015, Lex/el.

36 Wyrok NSA z dnia 13 maja 2009 r., II FSK 139/08, CBOSA.

37 Por. P. Przybysz, Komentarz do art. 81 k.p.a..., Lex/el; wyrok WSA w Bydgoszczy z dnia 14 kwietnia 2015 r., I SA/Bd 94/15, CBOSA; B. Adamiak, Komentarz do art. 81 k.p.a. [w:] J. Borkowski, B. Adamiak, Kodeks postępowania administracyjnego. Komentarz 2017, Legalis/el.

38 A. Olesińska, Polskie prawo podatkowe, Toruń 2012, s. 207-208; wyroki WSA w Gliwicach z dnia 13 kwietnia 2012 r., III SA/Gl 890-891/11, CBOSA; B. Adamiak, Komentarz do art. 192 o.p. [w:] B. Adamiak, J. Borkowski, P. Borszowski, R. Mastalski, J. Zubrzycki, Ordynacja podatkowa. Komentarz 2017, Wrocław 2017, s. 1131.

39 B. Brzeziński (red.), M. Kalinowski (red.), A. Olesińska (red.), Ordynacja..., s. 946; wyrok WSA w Gorzowie Wielkopolskim z dnia 10 listopada 2010 r., I SA/Go 587/10, CBOSA.

40 Szerzej I. Nowak, I. Ledzion, Udostępnianie akt sprawy podatkowej, „Przegląd Podatków Lokalnych i Finansów Samorządowych” 2017, numery 4-5, s. 18-26/21-28. 
lub nie miały istotnego znaczenia dla sprawy, to w takiej sytuacji brak podstaw do twierdzenia, że doszło do naruszenia art. 192 o.p. czy art. 123 o.p. w związku z art. 200 § 1 o.p. ${ }^{41}$. Zgodnie więc z utrwalonym w piśmiennictwie poglądem, przyznanym podatnikowi prawem do wypowiedzenia się odnośnie przeprowadzonych dowodów strona rozporządza, co oznacza, że od jej woli zależy jego realizacja ${ }^{42}$. A czy strona z tej możliwości skorzysta, czy też nie, to jest już sprawa koncepcji obrony jej interesów ${ }^{43}$.

Organ administracji podatkowej zobligowany jest do stworzenia biernemu podmiotowi stosunku podatkowoprawnemu stosownych warunków do wypowiedzenia się w sprawie przeprowadzonych dowodów ${ }^{44}$, pamiętając m.in., że termin zakreślony podatnikowi do zapoznania się z zebranym w sprawie materiałem dowodowym musi być terminem realnym $^{45}$. Tytułem przykładu: skoro strona nie została zawiadomiona o przeprowadzeniu dowodu z przesłuchania świadka ${ }^{46}$, a zatem nie miała możliwości wypowiedzenia się, to - zgodnie z art. 192 o.p. - okoliczności faktyczne, które były stwierdzone powyższym dowodem, nie można uznać za udowodnione i należy je powtórzyć w prawidłowym trybie procedowania $^{47}$. Oczywistym jest przy tym, że w świetle art. 192 o.p. podatnikowi należy zapewnić realną możliwość zrozumienia oraz zajęcie stanowiska dotyczącego danego dowodu ${ }^{48}$. Zbieżnie wypowiada się w powyższej kwestii orzecznictwo, zgodnie z którym jeżeli osoba reprezentująca dłużnika podatkowego w jurysdykcyjnym postępowaniu podatko-

41 Wyrok NSA z dnia 26 kwietnia 2016 r., I GSK 1140/14, CBOSA.

42 B. Adamiak, Komentarz do art. 192 o.p..., s. 1131.

43 Wyrok WSA w Łodzi z dnia 22 grudnia 2004 r., III SA/Łd 694/04, CBOSA; wyrok WSA w Warszawie z dnia 6 czerwca 2018 r., V SA/Wa 1107/17, CBOSA.

44 Por F. Elżanowski, Komentarz do art. 81 k.p.a. [w:] R. Hauser (red.), M. Wierzbowski (red.), Kodeks postępowania administracyjnego. Komentarz 2018, Legalis/el.

45 Por. wyrok NSA z dnia 10 grudnia 1997 r., I SA/Gd 409/96, CBOSA; wyrok NSA z dnia 17 kwietnia 2008 r., I OSK 644/07, CBOSA.

46 I. Nowak, Dowód z zeznań świadka na gruncie jurysdykcyjnego postępowania podatkowego, „Prawo Budżetowe Państwa i Samorządu” 2019, nr 1, DOI: http://dx.doi.org/ 10.12775/PBPS.2019.007, s. 154-155.

47 I. Nowak, Dowód z przesłuchania strony w procedurze podatkowej - uwagi de lege lata i de lege ferenda, „Toruński Rocznik Podatkowy” 2018/el, w druku; wyrok NSA z dnia 3 lutego 2000 r., I SA/Kr 277/99, CBOSA.

48 Por. J. Borkowski, Komentarz do art. 79 k.p.a..., s. 160. 
wym - niebędąca obywatelem polskim i niewładająca w żadnym stopniu językiem polskim - uczestniczyła w czynnościach organu podatkowego jedynie w sensie fizycznym (bez udziału tłumacza), pozbawiona została tym samym możliwości zrozumienia istoty przeprowadzanych czynności dowodowych i faktycznej zdolności wypowiedzenia się co do treści tych dowodów $^{49}$, co w oczywisty sposób narusza jej prawo do obrony swoich interesów ${ }^{50}$.

„Wypowiedzenie” się podatnika w przedmiocie przeprowadzonych dowodów może przybrać formę zarówno pisemną, jak i ustną do protoko$\mathrm{u}^{51}$. Ponadto, zgodnie z zasadą pisemności, a tym samym pewności obrotu prawnego, czynny podmiot stosunku podatkowoprawnego powinien utrwalić w aktach sprawy fakt skorzystania/wypowiedzenia się (lub nie) podatnika w świetle art. 192 o.p. w związku z art. 123 o.p. i art. 200 o.p. ${ }^{52}$. Przy czym zauważyć należy, że możliwość wypowiedzenia się strony, o jakiej mowa w art. 192 o.p., należy odnieść zarówno do całokształtu materiału dowodowego w sprawie, jak i do poszczególnych dowodów ${ }^{53}$. Odnotować w tym miejscu należy, że brak w aktach sprawy podatkowej informacji, że organ prowadzący postępowanie pouczył podatnika o przysługującym mu prawie z art. 192 o.p. w związku z art. 123 i art. 200 o.p., uzasadnia wniosek, że doszło do naruszenia zasady czynnego udziału strony oraz zasady prawdy materialnej ${ }^{54}$. Nie można zatem uznać, że okoliczność faktyczna został udowodniona, skoro w aktach sprawy, będących formalnym odzwierciedleniem całości materiału dowodowego, brak o tym informacji $^{55}$. Co więcej, zagwarantowanie podatnikowi możliwości wypowiedzenia się - polegającej, m.in. na złożeniu zarzutów, wniosków dowodowych czy też innych czynności zawierających ustosunkowanie się

\footnotetext{
Wyrok WSA w Bydgoszczy z dnia 23 maja 2007 r., I SA/Bd 291/07, CBOSA.

Por. G. Łaszczyca, Postanowienie administracyjne w ogólnym postępowaniu administracyjnym 2012, Lex/el.

Por. H. Knysiak-Molczyk (red.), Kodeks..., Lex/el.

52 Por. W. Bochenek, Komentarz do art. 81 k.p.a..., s. 365.

53 Wyrok NSA z dnia 26 października 2001 r., I SA/Lu 1021/00, CBOSA; J. Zimmermann, Ordynacja podatkowa. Komentarz. Postępowanie podatkowe, Toruń 1998, s. 165.

54 Por. wyrok NSA z dnia 2 czerwca 1999 r., V SA 1106/98, CBOSA; wyrok WSA w Krakowie z dnia 26 czerwca 2015 r., II SA/Kr 213/15, CBOSA.

55 Por. J. Borkowski, Komentarz do art. 80 k.p.a..., s. 161.
} 
co do zebranego materiału dowodowego - organ podatkowy powinien dokonać poprzez prawidłowe poinformowanie go o sposobie i terminie skorzystania z przysługującego mu uprawnienia ${ }^{56}$.

\section{Włączanie dowodów $\mathrm{z}$ innych postępowań do procedury podatkowej a prawo podatnika do wypowiedzenia się}

Dopuszczalność włączania do akt procesu podatkowego, np. protokołów przesłuchań świadków z innych postępowań, nie powoduje naruszenia przepisów procedury podatkowej pod warunkiem, że podatnik ma możliwość wypowiedzenia się co do tych dowodów ${ }^{57}$. Posłużenie się więc zeznaniami świadków, którzy przesłuchani zostali w odrębnym od podatkowego postępowaniu, np. karnym, jest w pełni zgodne $\mathrm{z}$ art. 180 § 1 o.p. oraz art. 181 o.p. ${ }^{58}$. Nie zmienia to jednak faktu, że powtórzenie określonych czynności dowodowych przeprowadzonych w toku innych procedur jest niezbędne jedynie wówczas, gdy ocena tych dowodów dokonana $\mathrm{w}$ powiązaniu $\mathrm{z}$ materiałem dowodowym zebranym $\mathrm{w}$ postępowaniu podatkowym uniemożliwia jednoznaczne i prawidłowe ustalenie stanu faktycznego w sprawie ${ }^{59}$. Zwraca na to uwagę również judykatura, zauważając, że oczywiście istnieje możliwość ponownego przeprowadzenia dowodu, ale to żądanie będzie uzasadnione tylko wówczas, gdy strona

56 Por. W. Bochenek, Komentarz do art. 81 k.p.a. [w:] L. Klat-Wertelecka (red.), A. Mudrecki (red.), Kodeks postępowania administracyjnego. Komentarz dla praktyków, Gdańsk 2012, s. 365.

57 D. Dominik-Ogińska, Przesłuchanie świadka, „Biuletyn Krajowej Izby Doradców Podatkowych” 2018, nr 3, s. 11 i n.; wyrok NSA z dnia 16 grudnia 2016 r., II FSK 3494/14, CBOSA; wyrok NSA z dnia 10 stycznia 2017 r., II FSK 2992/15, CBOSA; wyrok NSA z dnia 2 lutego 2017 r., II FSK 4127/14, CBOSA; wyrok NSA z dnia 5 maja 2017 r., II FSK 973/15, CBOSA.

58 Wyrok NSA z dnia 26 kwietnia 2017 r., II FSK 923/15, CBOSA; wyrok NSA z dnia 1 grudnia 2017 r., II FSK 3261/15, CBOSA; wyrok WSA w Gliwicach z dnia 5 lipca 2018 r., I SA/Gl 207/18, CBOSA.

59 Wyrok NSA z dnia 16 stycznia 2014 r., I FSK 228/13, CBOSA; wyroki NSA z dnia 6 lutego 2015 r., I FSK 2112-2113/13, CBOSA; wyrok WSA w Szczecinie z dnia 21 czerwca 2018 r., I SA/Sz 1009/17, CBOSA; wyrok WSA w Białymstoku z dnia 29 sierpnia 2018 r., I SA/Bk 16/18, CBOSA. 
wskaże na konkretne i istotne okoliczności faktyczne niezbędne do wyjaśnienia sprawy lub sprzeczności w tych zeznaniach w porównaniu z już zebranym materiałem dowodowym ${ }^{60}$.

W związku z powyższym nie ma podstaw, aby wbrew art. 180 o.p. i art. 181 o.p. materiały np. z postępowania karnego generalnie traktować, czy to jako dowody stanowiące tzw. owoc zakazanego drzewa, czy też nakazywać organowi podatkowemu ponowne ich przeprowadzenie z urzędu ${ }^{61}$. Odnotować w tym miejscu należy, że w polskim postępowaniu podatkowym nie obowiązuje zasada bezpośredniości, a stan faktyczny może zostać ustalony na podstawie dowodów przeprowadzonych przez inny organ ${ }^{62}$. Tym samym twierdzenie przeciwne jest wadliwe, chociażby z punktu widzenia zasady racjonalności prawodawcy i wewnętrznej niesprzeczności prawa, ponieważ jeżeli jeden przepis prawa dopuszcza możliwość określonego działania, to skorzystanie z niej nie może być jednocześnie uznane za naruszające inne normy prawne ${ }^{63}$. Należy zatem przyjąć, że dowody zgromadzone w innym postępowaniu niż podatkowe będą stanowić środek dowodowy dopuszczalny w procedurze podatkowej na równi z pozostałymi dowodami i pomimo, że nie zostały przeprowadzone bezpośrednio przez organ podatkowy, podlegają, tak jak i pozostałe dowody, swobodnej jego ocenie ${ }^{64}$. Przy czym taki dowód nie może być przyjmowany przez podatkowe organy procesowe w sposób bezkrytyczny ${ }^{65}$.

60 Wyrok WSA w Bydgoszczy z dnia 20 lutego 2018 r., I SA/Bd 987/17, CBOSA; wyrok WSA w Lublinie z dnia 23 marca 2018 r., I SA/Lu 57/18, CBOSA.

61 H. Sęk, P. Pietrasz, Zeznania, wyjaśnienia, oświadczenia jako dowód w postępowaniu podatkowym - wybrane zagadnienia na tle orzecznictwa sq̨ów administracyjnych [w:] R. Dowgier (red.), Ordynacja podatkowa. Dowody w postępowaniu podatkowym, Białystok 2013, s. 14-15; wyrok WSA w Lublinie z dnia 26 września 2008 r., I SA/Lu 260/08, CBOSA; wyrok WSA w Lublinie z dnia 15 stycznia 2010 r., I SA/Lu 757/09, CBOSA; wyrok WSA w Warszawie z dnia 6 lipca 2017 r., III SA/Wa 1976/17, CBOSA. Wyrok WSA w Szczecinie z dnia 26 września 2018 r., II SA/Sz 297/18, CBOSA.

63 Por. wyrok WSA w Łodzi z dnia 12 grudnia 2018 r., I SA/Łd 538/18, CBOSA.

64 Por. A. Mariański, Swobodna czy dowolna ocena dowodów - teoria a praktyka, „Przegląd Podatkowy” 2008, nr 8, s. 7 i n.; wyrok WSA w Lublinie z dnia 22 listopada 2017 r., I SA/Lu 792/17, CBOSA; wyrok WSA w Lublinie z dnia 6 grudnia 2017 r., I SA/Lu 791/17, CBOSA; wyrok WSA w Lublinie z dnia 23 lutego 2018 r., I SA/Lu 945/17, CBOSA; wyrok WSA w Lublinie z dnia 27 kwietnia 2018 r., I SA/Lu 162/18, CBOSA.

65 D. Dominik-Ogińska, Przesłuchanie..., s. 16; D. Strzelec, Zasady postępowania dowodowego - uwagi o stosowaniu prawa przyczynkiem do dyskusji nad kształtem przy- 
A ponadto podatnik musi być „zaznajomiony” z dowodami zebranymi $\mathrm{w}$ ramach innego procesu $\mathrm{w}$ toku postępowania podatkowego, zmierzającego do wydania na tej podstawie prawidłowego rozstrzygnięcia podatkowego ${ }^{66}$. Warto też wskazać, że ocena dowodów zgromadzonych i rozpatrzonych z naruszeniem przepisów art. 192 o.p. musi być w każdym przypadku potraktowana nie jako swobodna ocena dowodów, lecz jako ocena dowolna ${ }^{67}$. Zwraca na to uwagę również orzecznictwo, zauważając, że w przypadku dowodów uzyskanych bez udziału podatnika przez włączenie do akt sprawy podatkowej protokołów przesłuchań z innych procedur - zasada czynnego udziału strony w postępowaniu (prawo strony do obrony jej stanowiska) ${ }^{68}$, realizowana jest poprzez zaznajomienie podatnika z tymi dowodami, co umożliwi mu wypowiedzenie się w ich zakresie i przedstawienie kontrdowodów ${ }^{69}$. Zgodzić się więc trzeba z P. Pietraszem, że „w postępowaniu podatkowym stronie należy umożliwić wypowiedzenie się także co do dowodów przeprowadzonych w innym postępowaniu, np. podatkowym, karnym lub karnym skarbowym, następnie włączonych do akt danego postępowania. W przeciwnym razie mamy do czynienia z naruszeniem art. 192 o.p.”70.

szłych regulacji prawnych, „Przegląd Podatkowy” 2014, nr 4, s. 12-17; por. wyrok NSA z dnia 29 maja 2018 r., I FSK 1542/16, CBOSA; wyrok NSA z dnia 14 czerwca 2018 r., II FSK 1670/16, CBOSA.

66 Por. I. Nowak, Correct structure of a tax decision in the light of legal and tax security of the individual [w:] K. Flaga-Gieruszyńska, E. Cała-Wacinkiewicz, D. Wacinkiewicz (red.), The safety of the individual and of the group in private and public law - a collection of studies, Gorzów Wielkopolski 2015, s. 141 i n.; P. Przybysz, Komentarz do art. 81 k.p.a..., Lex/el; wyrok NSA z dnia 3 grudnia 1982 r., SA/Kr 743/82, CBOSA.

67 Wyrok WSA w Gdańsku z dnia 20 lutego 2007 r., I SA/Gd 876/06, CBOSA; wyrok WSA we Wrocławiu z dnia 13 kwietnia 2015 r., III SA/Wr 897/14, CBOSA; wyrok NSA z dnia 19 maja 2016 r., II OSK 2242/14, CBOSA.

68 Szerzej A. Zdunek, Dopuszczenie jako dowodu w postepowaniu podatkowym materiałów zgromadzonych $w$ innych postępowaniach a zasada czynnego udziału strony w postępowaniu [w:] M. Popławski, Ordynacja podatkowa. Zagadnienia proceduralne, Białystok 2011, s. 149 i n.

69 Wyrok NSA z dnia 25 maja 2018 r., I FSK 1253/16, CBOSA; wyrok NSA z dnia 29 maja 2018 r., I FSK 1542/16, CBOSA; wyrok NSA z dnia 14 czerwca 2018 r., II FSK 1670/16, CBOSA.

70 P. Pietrasz, Komentarz do art. 192 o.p..., Lex/el; analogicznie E. Michna, Wpływ innych postępowań na postępowanie podatkowe [w:] B. Kucia-Guściora (red.), 


\section{Następstwa prawne naruszeń prawa podatnika do wypowiedzenia się co do przeprowadzonych dowodów}

Obowiązek przeprowadzenia całego postępowania podatkowego i zgromadzenia wszystkich istotnych okoliczności sprawy spoczywa na organie podatkowym i nie może być nigdy przerzucany na stronę ${ }^{71}$, ponieważ z naczelnej zasady procedury podatkowej wypływa powinność podjęcia przez czynny podmiot stosunku podatkowoprawnego wszelkich niezbędnych działań w celu dokładnego wyjaśnienia stanu faktycznego oraz załatwienia sprawy ${ }^{72}$.

Konsekwencje prawne naruszenia art. 192 o.p. przejawiają się na dwóch płaszczyznach: po pierwsze, możliwość wypowiedzenia się podatnika co do zgromadzonych dowodów jest przesłanką uznania wartości procesowej każdego, nawet najlepiej zebranego i wszechstronnie ocenionego materiału dowodowego. Oznacza to, że pozbawienie strony możliwości zapoznania się z tymi dowodami spowoduje, że nie będą one mieć w sprawie żadnego znaczenia jako pozbawione „mocy prawnej”73. Analogiczne stanowisko prezentowane jest także w orzecznictwie, zgodnie z którym zaniedbanie obowiązku z art. 192 o.p. powoduje, że dowody, co do których strona nie miała możliwości wypowiedzenia się, są bezwartościowe i nie mogą być wykorzystane do udowodnienia jakiejkolwiek okoliczności $^{74}$. Nie sposób więc uznać, aby realizacja zasady z art. 192 o.p. polegała jedynie na przedstawieniu podatnikowi dokumentu wskazującego, że dany dowód przeprowadzono, ponieważ skoro stronie odebrano

M. Münnich (red.), A. Zdunek (red.), Stanowienie i stosowanie prawa podatkowego w Polsce. Procesowe prawo podatkowe, Lublin 2013, s. 256.

71 Por. wyrok WSA w Łodzi z dnia 11 kwietnia 2018 r., I SA/Łd 97/18, CBOSA; wyrok WSA w Łodzi z dnia 11 kwietnia 2018 r., I SA/Łd 112/18, CBOSA.

72 Wyrok NSA z dnia 26 kwietnia 2018 r., II FSK 1017/16, CBOSA; wyrok WSA w Białymstoku z dnia 25 czerwca 2018 r., I SA/Bk 276/18, CBOSA.

73 R. Kędziora, Kodeks..., Lex/el; wyrok WSA w Gorzowie Wielkopolskim z dnia 10 listopada 2010 r., I SA/Go 587/10, CBOSA; wyrok WSA we Wrocławiu z dnia 28 stycznia 2011 r., I SA/Wr 1341/10, CBOSA; wyrok WSA w Krakowie z dnia 10 grudnia 2015 r., I SA/Kr 1560/15, CBOSA.

74 Wyrok NSA z dnia 8 lipca 1998 r., III SA 1375/97, Lex nr 44703. 
możliwość zapoznania się np. z opinią biegłego, przyjąć należy, że wartość tego dowodu jest „zerowa” ${ }^{\text {, }}$.

Po drugie, naruszenie przepisu art. 192 o.p. należy zaliczyć do istotnych wad procesu podatkowego ${ }^{76}$, powodujących uchylenie rozstrzygnięcia podatkowego $\mathrm{w}$ toku instancyjnym lub wznowienie postępowania podatkowego na podstawie art. $240 \S 1$ pkt 4 o.p. ${ }^{77}$ Inaczej rzecz ujmując, skutek procesowy niezachowania wymogu określonego w art. 192 o.p. sprowadza się do tego, że żadna okoliczność faktyczna ustalona bez udziału podatnika nie może być uznana za udowodnioną i stanowić będzie w przypadku decyzji ostatecznej przesłankę do wznowienia postępowania podatkowego $^{78}$. Co więcej, w orzecznictwie słusznie wskazuje się, że przesłanka wznowienia postępowania określona w art. $240 \S 1$ pkt 4 o.p. zostaje spełniona zarówno wtedy, gdy strona w ogóle nie brała udziału w postępowaniu podatkowym, ale także wtedy w niektórych czynnościach procesowych ${ }^{79}$, niezależnie od tego, czy miało to wpływ na wynik sprawy i treść rozstrzygnięcia, czy też nie, bowiem sam brak udziału stro-

75 D. Strzelec, Gromadzenie materiału dowodowego a gwarancje procesowe strony postępowania, „Prawo i Podatki” 2012, nr 4, s. 1 i n.; wyrok WSA w Gorzowie Wielkopolskim z dnia 8 maja 2008 r., I SA/Go 907/07, CBOSA.

76 Przepis art. 192 o.p. znajdzie również zastosowanie w postępowaniu przed organem podatkowym zobowiązanym do zajęcia stanowiska w sprawie w trybie art. 209 o.p. Zatem w przypadku naruszenia art. 192 o.p. w związku z art. 209 o.p. w sprawie zakończonej decyzją ostateczną wystąpi również przesłanka wznowienia postępowania podatkowego z art. $240 \S 1$ pkt 4 i 6 o.p. - por. wyrok NSA z dnia 22 lutego 1999 r., IV SA 2787/98, CBOSA; F. Elżanowski, Komentarz do art. 81 k.p.a. [w:] M. Wierzbowski (red.), A. Wiktorowska (red.), Kodeks postępowania administracyjnego. Komentarz 2017, Legalis/el.

77 H. Dzwonkowski, Z. Zgierski, Procedury podatkowe, Warszawa 2006, s. 817; wyrok WSA w Warszawie z dnia 18 września 2006 r., III SA/Wa 2139/06, CBOSA; wyrok WSA w Olsztynie z dnia 26 listopada 2009 r., I SA/Ol 647/09, CBOSA.

78 A. Hanusz, Zasada swobodnej oceny dowodów w postępowaniu podatkowym oraz jej granice, „Państwo i Prawo” 2001, nr 10, s. 64 i n.; wyrok WSA w Gorzowie Wielkopolskim z dnia 10 listopada 2010 r., I SA/Go 587/10, CBOSA.

79 Wyrok WSA w Gliwicach z dnia 30 listopada 2010 r., III SA/Gl 1600/10, CBOSA; wyrok WSA w Krakowie z dnia 10 stycznia 2018 r., I SA/Kr 1161/17, CBOSA; wyrok NSA z dnia 30 stycznia 2018 r., II FSK 122/16, CBOSA. 
ny bez jej winy stanowi dostateczną formalną podstawę do wznowienia procesu podatkowego ${ }^{80}$.

Tytułem podsumowania: jeżeli podatnik nie był zawiadomiony, a w konsekwencji nie brał udziału np. w przesłuchiwaniu świadków czy oględzinach i nie został zapoznany z przeprowadzanymi dowodami ani w sposób jednoznaczny wezwany do wypowiedzenia się w sprawie zebranego materiału dowodowego ${ }^{81}$ - czyli nie $\mathrm{z}$ własnej winy nie brał udziału w postępowaniu - należy stwierdzić, że postępowanie podatkowe prowadzone było z obrazą art. $240 \S 1$ pkt 4 o.p. i stanowi przesłankę wznowienia postępowania podatkowego.

\section{Podsumowanie}

Prawo podatkowe jako gałąź prawa o charakterze ingerencyjnym prowadzi do ograniczenia własności, przez co porównywane jest w literaturze przedmiotu do prawa karnego, ingerującego w sferę wolności człowieka ${ }^{82}$. Dlatego też organy podatkowe w inkwizycyjnej procedurze podatkowej zgodnie z zasadą prawdy obiektywnej wynikającą z art. 122 o.p. - muszą podejmować wszelkie niezbędne działania w celu dokładnego wyjaśnienia stanu faktycznego oraz załatwienia sprawy ${ }^{83}$. A zatem powinność ustalenia prawdy materialnej spoczywa na czynnym podmiocie stosunku podatkowoprawnego ${ }^{84}$, ponieważ ustawodawca - odmiennie niż w procedurze cywilnej - ukształtował model procesowego stosunku podatkowoprawnego na zasadzie inkwizycyjności, a nie kontradyktoryjności. Oczywistym

80 Wyrok NSA z dnia 17 sierpnia 1999 r., SA/Rz 282/99, CBOSA; wyrok NSA z dnia 3 lutego 2017 r., II FSK 2525/15, CBOSA.

81 I. Nowak, Istota i znaczenie wezwań w postępowaniu podatkowym, „Przegląd Podatków Lokalnych i Finansów Samorządowych” 2019, nr 7-8, w druku; tenże Wezwania w świetle pomocy prawnej pomiędzy organami administracji podatkowej na gruncie art. 157 i 157a Ordynacji podatkowej, „Kwartalnik Prawa Podatkowego” 2018, nr 3, w druku. B. Brzeziński, Prawo podatkowe. Zagadnienia teorii i praktyki, Toruń 2017, I. Nowak, Prawo podatkowe jako prawo publiczne w świetle jego odrębności jako gałęzi prawa wybrane zagadnienia [w:] P. Ruczkowski (red.), Prawo - społeczeństwo - jednostka. Człowiek - najlepsza inwestycja, Kielce 2010, s. 83 i n. 
jest przy tym, że podyktowane jest to przede wszystkim ingerencyjnością prawa podatkowego oraz względami ochrony podatnika jako słabszego niż organ podatkowy podmiotu stosunku podatkowoprawnego ${ }^{85}$.

Art. 192 o.p. nie normuje żadnego odrębnego i „samodzielnego” uprawnienia procesowego strony, lecz ustanawia „bezwzględny warunek proceduralny” uznania danej okoliczności faktycznej za udowodnioną czyli możność wypowiedzenia się podatnika co do przeprowadzonych dowodów $^{86}$. Stąd też „konstrukcja prawna” art. 192 o.p. adresowana jest do organów administracji podatkowej, które nie mogą uznać danej okoliczności za udowodnioną, jeżeli w aktach sprawy podatkowej brakuje protokołu/adnotacji, że podatnikowi umożliwiono wypowiedzenie się co do przeprowadzonych dowodów ${ }^{87}$. Pamiętać przy tym należy, że dla uznania danej okoliczności faktycznej za udowodnioną nie ma znaczenia moment, w którym podatnik wypowiedział się co do przeprowadzonych dowodów $^{88}$. Trafne jest więc stanowisko judykatury, że obowiązek zapewnienia stronom czynnego udziału w postępowaniu podatkowym obejmuje wszystkie jego fazy, tj. zarówno fazę wszczęcia postępowania, fazę postępowania wyjaśniającego, fazę między zakończeniem postępowania wyjaśniającego a wydaniem decyzji oraz fazę wydawania indywidualnego aktu podatkowego ${ }^{89}$.

W trakcie jurysdykcyjnego postępowania podatkowego strona ma prawo wypowiedzenia się co do każdego dowodu, w przeprowadzeniu którego uczestniczyła. Jednakże obowiązek uregulowany w art. 192 o.p. zostanie w całości skonkretyzowany dopiero w sytuacji, gdy organ prowadzący postępowanie umożliwi podatnikowi wypowiedzenie się co do

85 Wyrok WSA w Gliwicach z dnia 10 stycznia 2017 r., III SA/Gl 2104/15, CBOSA; wyrok WSA w Gliwicach z dnia 11 stycznia 2017 r., III SA/Gl 2096/15, CBOSA.

86 Por. Z. Janowicz, Kodeks postępowania administracyjnego. Ustawa o Naczelnym Sqqdzie Administracyjnym. Komentarz 1996, Lex/el; A. Wróbel, Komentarz do art. 81 k.p.a..., Lex/el; Z.R. Kmiecik, Wszczęcie ogólnego postępowania administracyjnego 2014, Lex/el.

87 Por A. Wróbel, Komentarz do art. 81 k.p.a..., Lex/el.

88 Wyrok NSA z dnia 19 maja 2016 r., II OSK 2242/14, CBOSA.

89 Wyrok NSA z dnia 14 marca 2014 r., II GSK 92/13, CBOSA; wyrok NSA z dnia 14 stycznia 2015 r., I OSK 1614/14, CBOSA; wyrok NSA z dnia 14 czerwca 2016 r., II OSK 2473/14, CBOSA. 
ogółu „przeprowadzonych dowodów” zmierzających do ustalenia określonej okoliczności faktycznej ${ }^{90}$. Wskazać także należy, że ustawodawca w art. 192 o.p. zasadnie używa liczby mnogiej („przeprowadzonych dowodów”), ponieważ „dopiero całościowe zapoznanie się strony z materiałem dowodowym pozwoli jej na pełne ustosunkowanie się do każdego z dowodów z osobna oraz w konfrontacji z innymi dowodami"91.

$\mathrm{Z}$ zasady czynnego udziału strony w postępowaniu podatkowym, określonej w art. 123 o.p. i realizowanej poprzez art. 200 o.p., mowa jest o ,zebranych dowodach i materiałach/zebranych materiałach dowodowych”, natomiast art. 192 o.p. stanowi o uznaniu okoliczności faktycznej za udowodnioną, jeżeli strona miała możliwość wypowiedzenia się co do „przeprowadzony dowodów”. W związku z tym należy przyjąć, że „przeprowadzenie dowodu oznacza ujawnienie środka dowodowego ukrytego w źródle dowodowym"92, co oznacza, że chodzi tu nie tylko o dowody uzyskane przez organ prowadzący postępowanie w czasie jego trwania, ale także dowody, którymi „dysponuje” z urzędu³, np. dokumenty urzędowe, ewidencje itp. ${ }^{94}$. Podobne stanowisko prezentowane jest także w orzecznictwie, w którym podniesiono, że obowiązkiem organu administracji podatkowej jest zapewnienie podatnikowi możności wypowiedzenia się co do wszelkich dowodów zebranych w toku procesu podatkowego, co odnieść trzeba również do faktów znanych organowi podatkowemu z urzędu ${ }^{95}$, które zgodnie z art. 187 § 3 o.p. należy zakomunikować stronie $^{96}$. Wydaje się jednak - jak zasadnie podkreślono w piśmiennictwie że z zakresu pojęcia „przeprowadzone dowody” należy wyłączyć dowody

\footnotetext{
90 R. Kędziora, Kodeks..., Lex/el.

91 Por. W. Bochenek, Komentarz do art. 81 k.p.a..., s. 365; R. Kędziora, Kodeks..., Lex/el.

92 Z.R. Kmiecik, Wypowiedzenie się strony po przeprowadzeniu dowodów w postępowaniu administracyjnym, „Monitor Prawniczy” 2008, nr 6, s. 333 i n. Tamże; por. wyrok WSA w Łodzi z dnia 15 czerwca 2010 r., II SA/Łd 366/10, CBOSA.

4 Zob. I. Nowak, Dokumenty urzędowe jako dowody w świetle procedury podatkowej, „Przegląd Podatków Lokalnych i Finansów Samorządowych” 2018, nr 2, s. 20 i n.; por. G. Łaszczyca, Komentarz do art. 81 k.p.a. [w:] G. Łaszczyca, Cz. Martysz, A. Matan, Kodeks postępowania administracyjnego. Komentarz 2010, Lex/el.

95 Por. I. Nowak, Postępowanie administracyjne. Podręcznik akademicki z orzecznictwem, Kielce 2012, s. 208.

96 Por. wyrok WSA w Łodzi z dnia 15 czerwca 2010 r., II SA/Łd 366/10, CBOSA.
} 
(dokumenty) przedstawione przez samego podatnika, a co za tym idzie, w tym przypadku organ orzekający będzie zwolniony z obowiązku wynikającego z art. 192 o.p. ${ }^{97}$.

Przedstawione uwagi prowadzą do ogólnego spostrzeżenia, zgodnie z którym art. 192 o.p., będący wyrazem zasady ogólnej czynnego udziału strony, odnosi zasadę „nic o podatniku bez podatnika” do „przeprowadzonych dowodów”, natomiast art. 123 o.p. i 200 o.p. do wszelkiego rodzaju „zebranych dowód/materiałów dowodowych” znajdujących się w aktach sprawy podatkowej ${ }^{98}$. Tym samym, zgodnie z zasadą racjonalnego ustawodawcy, przyjąć należy, że regulacja art. 192 o.p. w związku z art. 123 o.p. i art. 200 o.p. ma sens tylko w przypadku ścisłego przestrzeganie każdego przepisu postępowania podatkowego, gwarantującego pełną ochronę praw podatnika ${ }^{99}$. Rozumując a contrario, w świetle art. 192 o.p. brak miejsca na kwalifikacje ocenne ${ }^{100}$. Tytułem uzupełnienia warto także dodać, że kategoryczne sformułowanie przepisu art. 192 o.p. nie pozostawia wątpliwości, iż zachowanie określonych w nim wymagań, niezależnie od wagi i treści przeprowadzonego dowodu, jest bezwzględnym obowiązkiem organu administracji podatkowej, którego niewykonanie stanowi naruszenie przepisów o postępowaniu podatkowym, mającym istotny wpływ na wynik sprawy ${ }^{101}$.

Przepis art. 192 o.p. jest normatywną konkretyzacją i rozwinięciem zasady czynnego udziału strony w postępowaniu, ustanawiającą fikcję braku udowodnienia okoliczności faktycznej, jeżeli podatnik nie miał możliwości wypowiedzenia się w sprawie ${ }^{102}$. Jak wskazano w orzecznictwie, rygorystyczne przestrzeganie przepisu art. 192 o.p. w związku z art. 200 o.p. przez organy administracji publicznej jest uzasadnione zarówno tym, że gwarantują one realizację zasady udziału strony w postępowaniu,

97 Z.R. Kmiecik, Wypowiedzenie..., s. 333.

98 E. Iserzon, Komentarz do art. 75 k.p.a..., s. 168.

99 H. Dzwonkowski, J. Gorąca, Komentarz do art. 192 o.p. [w:] H. Dzwonkowski (red.), Ordynacja podatkowa. Komentarz 2019, Legalis/el.

100 H. Dzwonkowski, Komentarz do art. 192 o.p. [w:] H. Dzwonkowski, A. Huchla, C. Kosikowski, Ordynacja podatkowa. Komentarz 2003, Lex/el.

101 Por. wyrok NSA z dnia 13 lutego 1986 r., II SA 2015/85, CBOSA; wyrok NSA z dnia 14 marca 2018 r., II OSK 3154/17, CBOSA.

102 H. Dzwonkowski, Komentarz do art. 192 o.p..., Lex/el. 
jak i tym, że tylko wówczas dana okoliczność faktyczna może być uznana za udowodnioną, gdy organ procesowy zapewnił podatnikowi możność wypowiedzenia się co do przeprowadzonych dowodów. Przepis ten nie wymaga natomiast, aby strona rzeczywiście wypowiedziała się co do wszystkich dowodów - wystarczy, aby z akt sprawy wynikało, że czynny podmiot stosunku podatkowoprawnego zapewnił jej taką możliwość ${ }^{103}$.

\section{Bibliografia:}

Adamiak B., Komentarz do art. 81 k.p.a. [w:] J. Borkowski, B. Adamiak, Kodeks postępowania administracyjnego. Komentarz 2017, Legalis/el.

Adamiak B., Komentarz do art. 192 o.p. [w:] B. Adamiak, J. Borkowski, P. Borszowski, R. Mastalski, J. Zubrzycki, Ordynacja podatkowa. Komentarz 2017, Unimex, Wrocław 2017.

Bochenek W., Komentarz do art. 81 k.p.a. [w:] L. Klat-Wertelecka (red.), A. Mudrecki (red.), Kodeks postępowania administracyjnego. Komentarz dla praktyków, ODDK, Gdańsk 2012.

Borkowski J., Komentarz do art. 81 k.p.a. [w:] J. Borkowski, J. Jendrośka, R. Orzechowski, A. Zieliński, Kodeks postępowania administracyjnego. Komentarz, WP, Warszawa 1985.

Brzeziński B., Masternak M., O tak zwanym ciężarze dowodu w postępowaniu podatkowym, „Przegląd Podatkowy” 2004, nr 5, s. 56-59.

Brzeziński B., Prawo podatkowe a prawo cywilne [w:] Brzeziński B. (red.), Prawo podatkowe. Teoria. Instytucje. Funkcjonowanie, TNOiK, Toruń 2009.

Brzeziński B., Kalinowski M., Olesińska A. (red.), Ordynacja podatkowa. Komentarz praktyczny, ODDK, Gdańsk 2017.

Brzeziński B., Prawo podatkowe. Zagadnienia teorii i praktyki, TNOiK, Toruń 2017.

Dauter B., Komentarz do art. 192 o.p. [w:] S. Babiarz, B. Dauter, R. Hauser, A. Kabat, M. Niezgódka-Medek, J. Rudowski, Ordynacja podatkowa. Komentarz 2017, Lex/el.

Dominik-Ogińska D., Przesłuchanie świadka, „Biuletyn Krajowej Izby Doradców Podatkowych” 2018, nr 3, s. 11-18.

Dzwonkowski H., Komentarz do art. 192 o.p. [w:] H. Dzwonkowski, A. Huchla, C. Kosikowski, Ordynacja podatkowa. Komentarz 2003, Lex/el.

Dzwonkowski H., Zgierski Z., Procedury podatkowe, Difin, Warszawa 2006.

103 Wyrok WSA we Wrocławiu z dnia 8 maja 2014 r., II SA/Wr 56/14, CBOSA. 
Dzwonkowski H., Gorąca J., Komentarz do art. 192 o.p. [w:] H. Dzwonkowski (red.), Ordynacja podatkowa. Komentarz 2019, Legalis/el.

Elżanowski F., Komentarz do art. 81 k.p.a. [w:] M. Wierzbowski, A. Wiktorowska (red.), Kodeks postępowania administracyjnego. Komentarz 2017, Legalis/el.

Elżanowski F., Komentarz do art. 81 k.p.a. [w:] R. Hauser (red.), M. Wierzbowski (red.), Kodeks postępowania administracyjnego. Komentarz 2018, Legalis/el.

Etel L. (red.), Nowa Ordynacja podatkowa. Z prac Komisji Kodyfikacyjnej Ogólnego Prawa Podatkowego, Temida 2, Białystok 2017.

Hanusz A., Zasada swobodnej oceny dowodów w postępowaniu podatkowym oraz jej granice, „Państwo i Prawo” 2001, nr 10, s. 64-78.

Hanusz A., Podstawa faktyczna rozstrzygnięcia podatkowego 2004, Lex/el.

Iserzon E., Komentarz do art. 75 k.p.a. [w:] E. Iserzon, J. Starościak, Kodeks postępowania administracyjnego. Komentarz. Teksty. Wzory i formularze, WP, Warszawa 1970.

Janowicz Z., Kodeks postępowania administracyjnego. Ustawa o Naczelnym Sqqdzie Administracyjnym. Komentarz 1996, Lex/el.

Kędziora R., Kodeks postępowania administracyjnego. Komentarz 2017, (komentarz do art. 81), Legalis/el.

Kmieciak Z., Odwołania w postępowaniu administracyjnym 2011, Lex/el.

Kmiecik Z.R., Wypowiedzenie się strony po przeprowadzeniu dowodów w postępowaniu administracyjnym, „Monitor Prawniczy” 2008, nr 6, s. 333-336.

Kmiecik Z.R., Wszczęcie ogólnego postępowania administracyjnego 2014, Lex/el.

Knysiak-Molczyk H. (red.), Kodeks postępowania administracyjnego. Komentarz 2015, (komentarz do art. 81), Lex/el.

Łaszczyca G., Komentarz do art. 81 k.p.a. [w:] G. Łaszczyca, Cz. Martysz, A. Matan, Kodeks postępowania administracyjnego. Komentarz 2010, Lex/el.

Łaszczyca G., Postanowienie administracyjne w ogólnym postępowaniu administracyjnym 2012, Lex/el.

Mariański A., Swobodna czy dowolna ocena dowodów - teoria a praktyka, „Przegląd Podatkowy” 2008, nr 8, s. 7-12.

Mariański A. (red.), Podatnik w postępowaniu podatkowym, C.H. Beck, Warszawa 2006.

Mariański A., Rozstrzyganie wątpliwości na korzyść podatnika. Zasada prawa podatkowego, Wolters Kluwer, Warszawa 2009.

Mastalski R., Stosowanie prawa podatkowego 2008, Lex/el.

Mastalski R., Tworzenie prawa podatkowego a jego stosowanie 2016, Lex/el. 
Michna E., Wpływ innych postępowań na postępowanie podatkowe [w:] B. KuciaGuściora, M. Münnich, A. Zdunek (red.), Stanowienie i stosowanie prawa podatkowego w Polsce. Procesowe prawo podatkowe, KUL, Lublin 2013.

Münnich M., Przebieg postępowania podatkowego (tryby zwyczajne i tryby nadzwyczajne) [w:] P. Smoleń, W. Wójtowicz (red.), Prawo podatkowe, C.H. Beck, Warszawa 2017.

Nowak I., Zasada dwuinstancyjności a ochrona praw podatnika, „Kwartalnik Prawa Podatkowego" 2009, nr 2, s. 9-36.

Nowak I., Prawo podatkowe jako prawo publiczne w świetle jego odrębności jako gałęzi prawa - wybrane zagadnienia [w:] P. Ruczkowski (red.), Prawo - społeczeństwo - jednostka. Człowiek - najlepsza inwestycja, WSEiP, Kielce 2010.

Nowak I., Postępowanie administracyjne. Podręcznik akademicki z orzecznictwem, WSEiP, Kielce 2012.

Nowak I., Skutki pominięcia pełnomocnika w sprawie podatkowej [w:] R. Frey (red.), Przemiany prawa publicznego i prywatnego na poczqtku XXI wieku, WSEiP, Kielce 2012.

Nowak I., Pełnomocnik jako reprezentant strony w jurysdykcyjnym postępowaniu podatkowym - wybrane aspekty, „Przegląd Prawa Publicznego” 2013, nr 12, s. 45-57.

Nowak I., Rutkowski B., Pełnomocnictwo w świetle Ordynacji podatkowej - stan obecny a planowane zmiany, „Toruński Rocznik Podatkowy” 2014/el, s. 184-204.

Nowak I., Correct structure of a tax decision in the light of legal and tax security of the individual [w:] K. Flaga-Gieruszyńska, E. Cała-Wacinkiewicz, D. Wacinkiewicz (red.), The safety of the individual and of the group in private and public law - a collection of studies, WSZGW, Gorzów Wielkopolski 2015.

Nowak I., Ciężar dowodzenia w postępowaniu podatkowym - podstawowe problemy [w:] B. Kucia-Guściora, M. Münnich, A. Zdunek, R. Zieliński (red.), Stanowienie i stosowanie prawa podatkowego w Polsce. Ocena i kierunki zmian, KUL, Lublin 2016.

Nowak I., Ledzion I., Udostępnianie akt sprawy podatkowej, „Przegląd Podatków Lokalnych i Finansów Samorządowych” 2017, nr 4-5, s. 17-23/17-21.

Nowak I., Dowód z przesłuchania strony w procedurze podatkowej - uwagi de lege lata $i$ de lege ferenda, „Toruński Rocznik Podatkowy” 2018/el, w druku. 
Nowak I., Dokumenty urzędowe jako dowody w świetle procedury podatkowej, „Przegląd Podatków Lokalnych i Finansów Samorządowych” 2018, nr 2, s. 20-27.

Nowak I., Wezwania w świetle pomocy prawnej pomiędzy organami administracji podatkowej na gruncie art. 157 i 157a Ordynacji podatkowej, „Kwartalnik Prawa Podatkowego" 2018, nr 3, w druku.

Nowak I., Status biegłego i jego opinii jako dowodu w jurysdykcyjnym postępowaniu podatkowym, „Przegląd Podatków Lokalnych i Finansów Samorządowych” 2018, nr 4-6, s. 19-26/19-27/23-29.

Nowak I., Oględziny jako bezpośredni środek dowodowy w postępowaniu podatkowym, „Przegląd Podatków Lokalnych i Finansów Samorządowych” 2018, nr 11, s. 18-24.

Nowak I., Istota i znaczenie wezwań w postępowaniu podatkowym, „Przegląd Podatków Lokalnych i Finansów Samorządowych” 2019, nr 7-8, w druku.

Nowak I., Dowód z zeznań świadka na gruncie jurysdykcyjnego postępowania podatkowego, „Prawo Budżetowe Państwa i Samorządu” 2019, nr 1(7), s. 129-165, DOI: http://dx.doi.org/10.12775/PBPS.2019.007.

Olesińska A., Polskie prawo podatkowe, TNOiK, Toruń 2012.

Pietrasz P., Komentarz do art. 192 o.p. [w:] L. Etel (red.), Ordynacja podatkowa. Komentarz aktualizowany 2018, Lex/el.

Presnarowicz S., Zaskarżanie decyzji podatkowych w Polsce, Temida 2, Białystok 2014.

Przybysz P., Kodeks postępowania administracyjnego. Komentarz aktualizowany 2019, (komentarz do art. 81), Lex/el.

Sęk H., Pietrasz P., Zeznania, wyjaśnienia, oświadczenia jako dowód w postępowaniu podatkowym - wybrane zagadnienia na tle orzecznictwa sq̨dów administracyjnych [w:] R. Dowgier (red.), Ordynacja podatkowa. Dowody w postępowaniu podatkowym, Temida 2, Białystok 2013.

Strzelec D., Naruszenie przepisów postępowania przez organy podatkowe, Wolters Kluwer, Warszawa 2009.

Strzelec D., Gromadzenie materiału dowodowego a gwarancje procesowe strony postępowania, „Prawo i Podatki” 2012, nr 4, s. 1-7.

Strzelec D., Zasady postępowania dowodowego - uwagi o stosowaniu prawa przyczynkiem do dyskusji nad kształtem przyszłych regulacji prawnych, „Przegląd Podatkowy” 2014, nr 4, s. 12-17.

Strzelec D., Dowody i postępowanie dowodowe w prawie podatkowym 2015, Lex/el. 
Terlikowska M., Kodeks postępowania administracyjnego. Dowody. Komentarz 2017, (komentarz do art. 81), Legalis/el.

Wierzbowski M., Wiktorowska A., Zagadnienia ogólne [w:] M. Wierzbowski (red.), Postępowanie administracyjne - ogólne, podatkowe, egzekucyjne i przed sq̨dami administracyjnymi, C.H. Beck, Warszawa 2017.

Wróbel A., Komentarz do art. 81 k.p.a. [w:] A. Wróbel, M. Jaśkowska, M. Wilbrandt-Gotowicz, Komentarz aktualizowany Kodeksu postępowania administracyjnego 2018, Lex/el.

Zdunek A., Dopuszczenie jako dowodu w postepowaniu podatkowym materiałów zgromadzonych w innych postępowaniach a zasada czynnego udziału strony w postępowaniu [w:] M. Popławski, Ordynacja podatkowa. Zagadnienia proceduralne, Temida 2, Białystok 2011.

Zimmermann J., Ordynacja podatkowa. Komentarz. Postępowanie podatkowe, TNOiK, Toruń 1998. 